\title{
EFFECTIVENESS OF CSR ADVERTISING: THE ROLE OF REPUTATION, CONSUMER ATTRIBUTIONS AND EMOTIONS
}

\section{INTRODUCTION}

Nowadays there is consensus on the necessity for companies to integrate CSR principles into their culture and corporate behaviour; however, the debate arises when we consider how to communicate such strategies. Although it is of utmost importance for organizations to communicate their CSR initiatives (Türket et al. 2016), they have been traditionally reluctant to publicize them, for fear of creating false expectations and criticism from audiences (Schlegelmilch and Pollach, 2005; Pérez and Rodriguez del Bosque, 2012). This controversy makes CSR communication an interesting research field.

Among the tools used to convey CSR messages, advertising is highlighted. Taking into account that communication of social information via advertising is more susceptible to provoking undesired reactions and consumer scepticism with respect to other communication sources (Yoon et al. 2006; Morsing and Schultz, 2006; Pomering and Johnson, 2009), previous research has mainly focused on analysing how to inhibit scepticism in order to obtain positive responses from consumers. In this way, this paper contributes to our growing understanding of CSR advertising by examining consumer reactions to advertising of a philanthropic cause. In particular, we intend to analyse antecedents and consequences of attitudes towards the CSR advertisement in a real context, with a causal model, which allowed us to gain understanding of the full picture of the process (Rifon et al. 2004).

With regard to the antecedents and with reference to previous works (Ellen et al. 2006; Du et al. 2010; Pomering et al. 2013), we consider that the perception of the prior ethical reputation of a company favours the CSR communication's effectiveness - that is, the attitude towards the advertisement - . However, and unlike others studies, we do not pose this relationship as direct but mediated by other variables. First, the importance of attributions is widely accepted. With regard to this, few studies have tried to detail explicitly the full range of motivations stakeholders may have when a company engages in CSR (Rifon et al. 2004; Ellen et al. 2006), and there is a lack of studies that analyse their specific role when explaining attitudes towards the advertisement. Secondly, we accept that the attitude is the result of a range of feelings and emotions (Batra and Ray, 1986; Homer and Yoon, 1992), which become important mediators of processing information (Percy, 2001). To the best of our knowledge, there are no studies that specifically measure the mix of emotions that a CSR advertisement provokes, both positive and negative. Therefore, we will attempt to contribute to the academic literature by studying: a) the range of consumer attributions linked to a CSR advertisement; b) how prior reputation influences attributions; c) the relationship between attributions and consumer emotional reactions; and d) the weight of such emotions in the formation of the attitude towards the advertisement.

Finally, the model analyses the consequences of attitudes towards a CSR advertisement, following the Dual Mediation Hypothesis (DMH), and the causal sequence between attitude towards the advertisement, attitude towards the brand and purchase intentions (MacKenzie and Lutz 1989; Lafferty et al. 2002). We specifically analyse the "rewards" 
of the CSR advertisement in terms of improvement of attitudes towards the brand and behavioural intention.

\section{LITERATURE REVIEW AND RESEARCH HYPOTHESES}

\subsection{Attributions and prior ethical reputation}

According to attribution theory (Kelley, 1973), individuals try to understand why companies support social causes and this evaluation leads them to consider two primary motivations: extrinsic or business-service versus altruistic or public-serving motives. The first motivations are linked to increasing sales or boosting the company's image, whereas the second motivations refer to benefits to society or raising awareness for a specific cause (Becker-Olsen et al. 2006).

These two types of motives have been traditionally conceived as extremes on a continuum where the consumer locates the general balance of why a company engages in a CSR campaign (Sen et al. 2006; Bigné, et al. 2010; Pérez and Rodríguez del Bosque, 2015). However, attribution theory suggests that there could be both negative and positive attributions, so it is better to measure polar perceptions independently rather than together. In this regard, Rifon et al. (2004) identify two types of non-altruistic attributions (profit and public image). Ellen et al. (2006) consider that consumers may carry out a complex inferential procedure, where mixed motives can be derived from the company's CSR engagement. In the Cause-related-Marketing (CrM) field, these authors found four different types of attributions; one referred to values and three to extrinsic motivations related to stakeholder, strategic and egoistic attributions.

In business communication, individuals usually initiate an attributional process which starts with extrinsic motives; that is, the audience considers that companies want to persuade them in order to achieve commercial benefits. However, in CSR communication the attribution of motivations is not always so simple, because these actions are related to activities that also benefit society. The audience will then apply a more extensive elaboration and during this process, they may generate multiple and rival hypotheses with regard to why certain actions - in this case the CSR activity - occur (Kelly, 1973). Consumers simultaneously attribute extrinsic and altruistic motivations to a CSR action, but they will discount the effect of one of them if they feel the other to be more dominant. This process of a two-step pattern of correcting one type of motivation for another is called the discounting principle (Kelly, 1973). When a company launches a CSR communication campaign, it needs to then ensure that consumers attribute strong altruistic motives to this action, with minimal perception of extrinsic motives resulting from scepticism. The prior ethical reputation of the firm can be a key condition to achieving this.

Ethical reputation often serves as a pre-existing schema upon which stakeholders rely to interpret ambiguous information about the company, including its new CSR activities (Elving, 2013; Du et al. 2010; Pomering et al. 2013). Consumers generally expect companies with a good ethical reputation to behave in a socially responsible way. When such companies carry out and communicate new initiatives, they will be perceived as sincere, inhibiting the generation of egoistic judgements, as opposed to companies with poor ethical reputations (Tao and Ferguson, 2015). Medium- or long-term commitment leads to more altruistic attributions (Ellen et al. 2006; Groza et al. 2011) and 
communication is more effective (Varadarajan and Menon, 1988). On the other hand, a bad reputation could increase the level of scepticism about the company's CSR activities (Lii and Lee, 2012; Elving, 2013) and short-term commitment may be viewed more as reactive to business demands.

Taking into account previous studies, we concur that when there is a good ethical reputation, consumers will perceive that the company is carrying out CSR activities to act on the principles of the organization; that is, to a greater extent for altruistic reasons. According to Rifon et al. (2004), it is not clear if the attributions of extrinsic motives may be reduced, or perhaps remain the same, but they may constitute a smaller proportion of the total motive judgments in these cases. These arguments lead to the proposition that:

H1. The prior ethical reputation will enhance altruistic attributions towards the advertisement of corporate philanthropy.

H2. The prior ethical reputation will reduce extrinsic attributions towards the advertisement of corporate philanthropy.

\subsection{Attributions and emotions in response to CSR advertising}

When people are exposed to a CSR communication, they ascribe different attributions that influence their evaluation of the advertisement. However, Batra and Ray (1986), Holbrook and Batra (1987), and Aaker et al. (1988) suggest that all the effects of feeling responses may not be captured by the attitude towards the advertisement, and add a previously neglected link in the form of a range of emotions. Emotional responses to advertising have been investigated extensively and diverse typologies have been developed. For example, Batra and Ray (1987) identify 13 categories of affective responses that include interest, surprise, scepticism and anger. Edell and Burke (1987) summarize 52 items in three dimensions: upbeat, negative, and warm feelings. Homer and Yoon (1992) consider attention, pleasure, scepticism and downbeat feelings. Later, Orth et al. (2007) worked with the constructs of downbeat feelings, pleasure and attention.

Positive and negative emotions are found to be independent and the presence of positive emotions does not preclude the presence of negative feelings; in fact, it is normal that both types of emotions co-occur (Huang, 2001; Williams and Aaker, 2002). This issue can emerge in CSR advertising. The main aim of a company is to make as much profit as possible, while donating money to a good cause is usually motivated by a willingness to help society. These contrary motives are not easily linked in the cognitive process of an individual (Elving, 2013). Everything will depend on the greater or minor weight of the altruistic versus extrinsic attributions inspired by the communication.

Altruistic motivations lead to more positive reactions of the audience (Forehand and Grier, 2003; Vlachos et al. 2009) and it is expected that these attributions generate positive emotions. On the other hand, extrinsic attributions may provoke negative reactions (Vlachos et al. 2009). For example, specific attributions of stakeholder-driven motives are likely to lead to negative feelings, because people believe the company is acting to avoid retribution from stakeholders and fear that a company's worthy programmes may disappear in the next downturn. Furthermore, unethical behaviour during the past decade has drawn intense media coverage and has increased public attention. A negative direct effect will dominate owing to consumer suspicion and public cynicism, with people's perception that companies pursue excessive profiteering and that 
they are not reciprocal with respect to causes (Vlachos et al. 2009). Despite these arguments, there are divergent opinions about extrinsic attributions. Consumers may legitimize profit-motivated giving, since corporate survival requires retaining customers and people can be even tolerant as long as CSR initiatives are also attributed to intrinsic motives (Ellen et al., 2006 and Du et al., 2010). Thus, it is likely that the activation of negative emotions can be reduced or neutralized when there is a strong attribution of intrinsic motives (Du et al., 2010). These arguments lead us to propose the following:

H3. Altruistic attributions towards the advertisement of corporate philanthropy will enhance positive emotions of consumers.

H4. Extrinsic attributions towards the advertisement of corporate philanthropy will enhance negative emotions of consumers.

H5. Altruistic attributions towards the advertisement of corporate philanthropy will reduce negative emotions of consumers.

These emotional responses will have varying effects on the attitude towards the advertisement (Aaker et al. 1988; Homer and Yoon, 1992). We accept that a CSR advertisement will provoke mixed attributions and mixed emotions that will impact on the evaluation of the advertisement. Not only can one simultaneously experience conflicting emotions, such a joint experience may be natural and frequently occurring (Huang, 2001; Williams and Aaker, 2002). This leads us to propose that:

H6. Positive emotions towards the advertising of corporate philanthropy will positively influence the attitude towards the ad.

H7. Negative emotions towards the advertising of corporate philanthropy will negatively influence the attitude towards the ad.

Finally, the causal sequence between attitude towards the advertisement, attitude towards the brand and purchase intentions - the three main measures of advertisement effectiveness - comprise the dual mediation hypothesis $(\mathrm{DMH})$, a model widely accepted in advertising, the order of effects of which appears to be robust (MacKenzie and Lutz 1989; Goldsmith et al. 2000; Lafferty et al. 2002). Thus, we support the DMH model and propose that:

H8. The attitude towards the advertising of corporate philanthropy will influence the attitude towards the brand.

H9. The attitude towards the brand will influence the behavioural intentions.

The model proposed is described in Figure 1.

\section{INSERT FIGURE 1}

\section{METHODOLOGY}

The hypotheses have been tested using a study focused on the financial sector. Financial entities have played an important role in the recent economic crisis and they have come under close scrutiny. In fact, financial entities are very active in CSR communication and 
they are the most heavily engaged in CSR of all industry sectors in recent years (Perez et al. 2015); however, the risk that their CSR actions generate scepticism is high. This makes the study of this sector especially interesting.

We carried out a field study using a real-world CSR initiative, which has the potential to shed much insight into the boundary conditions of social phenomena (Sen et al. 2006). Specifically, we followed the methodology of previous works (Rifon et al. 2004; Bigné et al. 2010 and García-de los Salmones et al. 2013), and measured adult individual perceptions of a fictitious advertisement of a real financial entity supporting a philanthropic cause. Compared with other strategies, - such as CrM (Ellen et al. 2006; Bigné et al. 2010), which is more clearly motivated by commercial factors and when properly executed helps to directly sell products and enhances financial performance (Brønn and Vrioni, 2001) - true philanthropy refers to a firm making a contribution to a worthy cause simply because the firm wishes to be a good citizen without any expectation of a benefit tied to that effort (Lii and Lee, 2012).

We presented to those surveyed two advertisements with the same social cause and two banks with different prior ethical reputations, in order to average the ethical reputation of the companies in the set of final data and ensure the variability needed to check the hypothesis in the causal model. We selected the two financial entities using a pre-test. As a result, Santander was chosen as the bank with a better prior ethical reputation and Bankia as the one with the poorest ethical reputation. Forty-five people aged between 18 and 45 participated in the study. With regard to the philanthropic activity, we chose an aid programme focused on disadvantaged children; this was a real programme and a real advertisement carried out by a financial entity (different from the one previously mentioned) several years ago. This activity was not known by the public; in fact, we ensured that people had no prior knowledge of this specific CSR action. Thus, the philanthropic activity was credible and realistic, and it had enough emotional charge to generate reactions in the audience.

The advertisements showed a colour picture of a child having breakfast, along with the Santander/Bankia logo and the headline "There are no children poor in love". There was a brief explanation of the aid programme with the text "Santander/Bankia invest time, effort and resources in programmes focused on the educational development and the welfare of over 200,000 disadvantaged boys and girls. In this way, we guarantee them access to something as basic as breakfast." Each advertisement was identical, with the exception of the financial entity.

The study population comprised Spanish people over 18 years old. The sample was chosen by convenience, although age and gender were controlled. The sample size was 225 (105 people evaluated the advertisement for Bankia, and 120 people evaluated the advertisement for Santander). We measured the variables using a 10-point Likert scale considering previous papers (see Appendix 1 for detail of the scales). Before carrying out the analysis we analysed the characteristics of the two samples and the prior ethical reputations of the companies to guarantee the homogeneity and the variability, respectively. As shown in Table 1, the respondents evaluated the banks slightly better when they were clients, although significant differences were confirmed between the perceptions of Bankia and Santander with regard to ethical reputation. 


\subsection{Validity of scales and measurement model}

First, we analysed the dimensionality of the scale of attributions with a principal components factor analysis (varimax rotation). The analysis derived a factorial structure composed of three factors, explaining $71.97 \%$ of the total variance (Table 2). The first factor included three items related to the intrinsic motivations of the companies, so we named these "altruistic attributions". The stakeholder attributions and the items related to egoistic goals of companies (in the Ellen et al. 2006 scale) were included in the same factor. People perceive all these issues to be closely related and in the same perceptual dimension (individuals perceive that companies assume that customers or society expect socially responsible behaviour, so they carry out philanthropic actions to attend to their demands and acquire more customers, retain clients and improve their image). We named these "business attributions". Finally, the third factor included other extrinsic attributions more directly related to the exploitation of the cause, so we named these "profit attributions”.

\section{INSERT TABLE 2}

We checked the reliability and validity of all the concepts by means of a first-order confirmatory factor analysis. The purpose of this step was to confirm the goodness of fit of the model, as well as the convergent and discriminant validity between the different constructs that it comprised. The results indicated goodness of fit indexes which were close to or exceeded the 0.9 threshold $(\mathrm{BBNFI}=0.869$; $\mathrm{BBNNFI}=0.937$; $\mathrm{CFI}=0.943$; IFI $=0.944$; RMSEA $=0.05$ ), which confirms the suitability of the model presented (Table 3). In all the cases, the alphas were above the minimum recommended value of 0.7 , which proved the internal reliability of the constructs. In addition, all the items were significant to a confidence level of $95 \%$ and their standardized lambdas were higher than 0.5 , which confirmed the convergent validity of the scales.

\section{INSERT TABLE 3}

The discriminant validity was evaluated using the confidence intervals for pairs of latent concepts. None of the confidence intervals calculated for the pairwise comparisons of the model variables included unity, so the proposed measurement model is correct (Table 4).

\section{INSERT TABLE 4}

\section{RESULTS}

The findings of the causal analysis are shown in Figure 2. In order to consider all the possibilities, we carried out the Lagrange Multiplier Test (LM Test) to test whether adding new relationships to the model would result in a significant improvement in model fit. According to the results, the inclusion of a new relationship between the two extrinsic attributions (business and profit attributions) created a statistically significant 
improvement in fit. Thus, we decided to include the relationship and look for a justification, which provides a new contribution.

The results confirm that there is a significant and positive effect of prior ethical reputation on altruistic attributions (confirming H1), as well as business attributions, whereas there is no effect on the perception of profit motivations. We had proposed that the prior ethical reputation reduced all the extrinsic attributions, but the results obtained seem to show the opposite; that is, it enhances them or there is no effect (H2 no supported). Thus, when people see an advertisement for a philanthropic cause, business attributions are activated independently of the prior ethical reputation of the company; that is, consumers think that companies are attending to the social demands of stakeholders in order to retain or attract clients. The fact that we are analysing a philanthropic activity (contribution to a worthy cause without any expectation of a benefit tied to that effort) could explain that profit attributions do exist, but they do not appear directly. Consumers perceive that business motivations lead companies to better economic results and other financial benefits (new relationship proposed by the LM Test).

With regard to emotions, altruistic attributions generate positive feelings (confirming H3) and they are capable of reducing negative feelings (confirming $\mathrm{H} 5$ ). $\mathrm{H} 4$ can be only partially confirmed because only the profit attributions provoke negative emotions anger, distrust or scepticism, among others - directly. As we expected, both positive and negative emotions influence attitudes towards the CSR advertisement (confirming H6 and H7). Taking into account the coefficients, the positive emotions have a higher weight, whereas the negative emotions are significant but with minor influence. Finally, the findings confirm the causal sequence attitude towards the advertisement, attitude towards the brand, and purchase intentions (confirming H7 and H8). Thus, CSR advertising can be effective and generate positive results in terms of better attitudes, loyalty and favourable word-of-mouth.

\section{CONCLUSIONS}

\section{INSERT FIGURE 2}

This paper attempts to contribute to the research field of CSR communication, with a causal model that tries to shed new light on the idiosyncrasies of advertising. Specifically, nine hypotheses were proposed regarding the determinants of attitudes towards an advertisement publicizing a philanthropic cause and its consequences in terms of improvement in attitude towards the brand and behavioural intentions. The study focused on the financial sector and we considered real banks linked to philanthropic causes (an aid programme for disadvantaged children), which was communicated through a print advertisement.

The findings of the paper generate several academic and managerial contributions. We can prove that exposure to a CSR advertisement engenders different attributions among consumers. As Rifon et al. (2004) and Ellen et al. (2006) established, attributions elicited by CSR activities are not simple bipolar judgements. In this way, we observed three types of attributions related to altruistic, business and profit attributions. The analysis of these specific drivers has given us a clearer view of the role of each type of perceived attribution in communication effectiveness and consumer behaviour. Some authors have found that prior CSR reputation enhances attribution values and can inhibit the generation of egoistic 
judgments. However, the results are not conclusive (Ellen et al. 2006; Groza et al. 2011). Our research shows that an advertisement communicating a philanthropic activity can directly provoke both value and business attributions and, indirectly, profit attributions. Business motivations are inevitable; this fact is understandable given that we are analysing for-profit companies. Companies have to survive and grow, so consumers perceive the CSR activities (in this case a philanthropic activity) as actions linked directly to business reasons; e.g., acquiring customers or improving image. The point is that intrinsic motives may be stronger than these extrinsic attributions. In order to communicate this, it is key to have a good ethical reputation. Prior ethical reputation does enhance altruistic attributions, which is essential for the effectiveness of advertising.

Previous researchers have found that altruistic attributions generate positive reactions in terms of improvement of image or corporate credibility, among other things. There is then a causal relationship between altruism and "reward" variables (Pérez and Rodríguez del Bosque, 2015). However, in the CSR field there is a lack of studies that analyse the mediator effects; that is, emotional responses and attitudes towards the advertisement. As we expected, intrinsic attributions lead to positive feelings, related to interest, affection, sympathy, curiosity and liking. With regard to extrinsic attributions, our study supports that people can be tolerant of these motives in certain circumstances; this adds a new insight. This study also highlighted that the relationship between business attributions and negative emotions is not significant. However, CSR advertising does provoke negative reactions due to the causal relationship identified between the two extrinsic attributions (business attributions lead inevitably to the perception of economic motivations). Emotions of scepticism, distrust, suspicion, anger and confusion are linked to the perception of profit attributions that can be generated by the CSR activity. However, these negative feelings are reduced when communication is able to activate altruistic attributions as well.

Consumers have a mix of both positive and negative emotions that influence their attitude towards the advertisement. As long as the advertisement generates a strong attribution of intrinsic motives, the positive emotions will have a higher weight in the evaluation and the general impression will be favourable. Finally, we support the robustness of the dual mediation hypothesis (Mackensie and Lutz, 1989). Analysing real companies, we measured the potential improvement in issues such as identification, trust or image, proving that a CSR advertisement can be effective and provoke strategic rewards in these terms. Likewise, the advertisement effectiveness is also supported in positive behavioural intentions, measured by favourable word-of-mouth and loyalty or intention of being a client of the entity.

Considering these results, we can advise companies in general - and financial entities in particular - to integrate CSR into their corporate culture and to implement responsible activities directed at all their stakeholders. CSR must not be only a principle declaration, but it has to materialize into concrete and continuous actions and be real. Everything communicates in an organization, so it has to be oriented towards CSR in order to be perceived as such in all its contacts with the public. The key is to have a good CSR reputation.

Companies can use a lot of controlled sources to publicize what they are doing in CSR activities; for example, social reports, web pages and advertising. With regard to advertising, there have been doubts about its suitability and effectiveness for 
communicating CSR actions, because it can raise the scepticism of the audience. Our research shows that CSR advertising can be effective. It is true that consumers perceive extrinsic motivations that provoke negative feelings, but if the company has achieved a good prior ethical reputation, altruistic attributions will be activated as well. These attributions will enhance positive emotions and will reduce the negative ones. As a result, the attitude towards the advertisement will be favourable, as will be the subsequent consumer reactions.

This paper has several limitations, which open up some future lines of research. First, the findings are limited to the context analysed. We used well-known financial entities and a philanthropic activity. Featuring other entities and CSR activities would extend the scope of the findings. Furthermore, it would be interesting to analyse other sectors, and consider low- and high-profile industries. Secondly, there were limitations in the field studies, with insufficient controls and real-world constraints; that is, our design could not entirely rule out the possibility that some respondents may have been more or less predisposed to the companies (Sen et al. 2006). Thirdly, it would be interesting to include other variables in the model and evaluate it using a multi-sample analysis. Thus, we could take into account the level of importance given to CSR, the fit between the social cause and the company, or consumer scepticism towards advertising. In this case, it can be expected that individuals who are sceptical towards advertising would be wary of CSR advertising to a higher extent. Finally, we have analysed ten emotions, previously defined by researchers. We propose to carry out further studies of an exploratory character, focused on measuring the full range of emotions generated by CSR advertising.

\section{REFERENCES}

Aaker, D., Stayman, D. and Vezina, R. 1988. Identifying Feelings Elicited by Advertising. Psychology \& Marketing, Spring 5 (1): 1-16.

Batra, R. and Ray, M. 1986. Affective Responses Mediating Acceptance of Advertising. Journal of Consumer Research; September 13 (2): 234-249.

Becker-Olsen, K., Cudmore, A. and Hill, R. 2006. The impact of perceived corporate social responsibility on consumer behavior. Journal of Business Research 59: 46- 53.

Bigné, E., Chumpitaz, Currás, R. 2010. Alliances Between Brands and Social Causes: The Influence of Company Credibility on Social Responsibility Image.Journal of Business Ethics 96:169-186

Bigné, E., Currás, R. and Sánchez, I. (2009) "Brand credibility in cause-related marketing: the moderating role of consumer values”, Journal of Product \& Brand Management, 18 (6), pp. 437-447.

Brønn, P. and Vrioni, A. 2001. Corporate social responsibility and cause-related marketing: an overview, International Journal of Advertising 20(2): 207-222

Du, S., Bhattacharya, C. and Sen, S. 2010. Maximizing Business Returns to Corporate Social Responsibility (CSR): The Role of CSR Communication. International Journal of Management Reviews 12 (1): 8-19.

Ellen, P., Webb, D. and Mohr, L. 2006. Building Corporate Associations: Consumer Attributions for Corporate Socially Responsible Programs. Journal of the Academy of Marketing Science 34 (2): 147-157. 
Elving, W. 2013. Scepticism and corporate social responsibility communications: the influence of fit and reputation. Journal of Marketing Communications 19 (4): 277-292.

Homer, P. and Yoon, S. 1992. Message Framing and the lnterrelationships Among AdBased Feelings, Affect, and Cognition. Journal of Advertising; 21 (1): 19-33.

García-De los salmones, M. Rodriguez-Del Bosque, I.and Herrero, A. 2005. Influence of Corporate Social Responsibility on Loyalty and Valuation of Services. Journal of Business Ethics 61: 369-385

García-de los Salmones, M., Dominguez, R. and Herrero, A. 2013. Communication using celebrities in the non-profit sector: determinants of its effectiveness. International Journal of Advertising 32 (1):. 101- 119

Gilbert, D. and Malone, P. 1995. The correspondence bias. Psychological Bulletin 117(1): 21-38.

Goldsmith, R., Lafferty, B. and Newell, S. 2000. The Impact of Corporate Credibility and Celebrity on Consumer Reaction to Advertisements and Brands. Journal of Advertising 29(3): 43-54

Groza, M., Pronschinske, M. and Walker, M. 2011. Perceived Organizational Motives and Consumer Responses to Proactive and Reactive CSR. Journal of Business Ethics 102:639-652

Homer, P. and Yoon, S. 1992. Message Framing and the Interrelationships among adbased feelings, affect and cognition. Journal of Advertising 21 (1): 19-33.

Huang, M. 2001. The Theory of Emotions in Marketing. Journal of Business and Psychology 16: 239.

Kelley, H. 1973. The Processes of Casual Attributions. American Psychologist, February: 107-128.

Lafferty, B.A., Goldsmith, R.E. and Newell, S.J. 2002. The Dual Credibility Model: The Influence of Corporate and Endorser Credibility on Attitudes and Purchase Intentions. Journal of

Lii, Y. and Lee, M. 2012. Doing Right Leads to Doing Well: When the Type of CSR and Reputation Interact to Affect Consumer Evaluations of the Firm. Journal of Business Ethics. 105 (1):69-81

MacKenzie, S.B. and Lutz, R.J. 1989. An Empirical Examination of the Structural Antecedents of Attitude Toward the Ad in an Advertising Pretesting Context. Journal of Marketing, 53: 48-65.

Morsing, M. and Schultz, M. 2006. Corporate social responsibility communication: Stakeholder information, response and involvement strategies. Business Ethics 15 (4):323-338

Pérez, A. and Rodríguez del Bosque 2015. The formation of customer CSR perceptions in the banking sector: the role of coherence, altruism, expertise and trustworthiness. International Journal of Business and Society 16 (1): 75 - 94

Perez, A., Garcia-De los Salmones, M. and Lopez, C. 2015. "Corporate reputation in the Spanish context: an interaction between reporting to stakeholders and industry. Journal of Business Ethics 129 (3):.571-584 
Pérez, A. y Rodríguez del Bosque, I. 2012. The role of CSR in the corporate identity of banking service providers. Journal of Business Ethics 108 (2): 145-166.

Percy, L. 2001. The Role of Emotion in Processing Low Involvement Advertising, in E - European Advances in Consumer Research Volume 5, eds. Andrea Groeppel-Klien and Frank-Rudolf Esch, Provo, UT : Association for Consumer Research, Pages: 293296.

Pomering, A. and Johnson, L. 2009. Advertising corporate social responsibility initiatives to communicate corporate image. Inhibiting scepticism to enhance persuasion. Corporate Communications: An International Journal 14 (4): 420-439.

Pomering, A., Johnson, L. and Noble, G. 2013. Advertising corporate social responsibility. Results from an experimental manipulation of key message variables. Corporate Communications: An International Journal 18 (2): 249-263

Rifon, N.,Choi, S. Trimble, C. Li, H. (2004). Congruence effects in sponsorship: The medicating role of sponsor credibility and consumer attributions of sponsor motive, Journal of Advertising, 33: 29-42

Sen, S., Bhattacharya, C. and Korschun, D. 2006. The Role of Corporate Social Responsibility in Strengthening. Multiple Stakeholder Relationships: A Field Experiment. Journal of the Academy of Marketing Science 34 (2): 158-166.

Schlegelmilch, B. B., Pollach, I., 2005. The perils and opportunities of communicating corporate ethics. Journal of Marketing Management 3-4 (21), 267-290.

Tao, W., \& Ferguson, M. 2015. The Overarching Effects of Ethical Reputation Regardless of CSR Cause Fit and Information Source. International Journal of Strategic Communication 9 (1): 23-43.

Türkel, s., Uzunoğlu, E. M, Demirbağ, M. and Akınc1, B. 2016. A Strategic Approach to CSR Communication: Examining the Impact of Brand Familiarity on Consumer Responses. Corporate Social Responsibility and Environmental Management 23: 228242

Vlachos, P., Tsamakos, A., Vrechopoulos, A. and Avramidis, P. 2009: Corporate social responsibility: attributions, loyalty, and the mediating role of trust. Journal of the Academy Marketing. Science 37:170-180

Williams, P. \& Aaker, J. 2002. Can Mixed Emotions Peacefully Coexist?, Journal of Consumer Research 28(4):636-49

Yoon, Y., Giirhan-Canli, Z. and Schwarz, N. 2006. The Effect of Corporate Social Responsibility Activities on Companies With Bad Reputations. Journal of Consumer Psychology 16(4): 377-390

APPENDIX 1

\begin{tabular}{|l|l|l|}
\hline VARIABLE & ITEMS & AUTHORS \\
\hline ETHICAL REPUTATION & $\begin{array}{l}\text { Behaves honestly with all its stakeholders } \\
\text { Has ethical principles well defined } \\
\text { Makes truthful claims } \\
\text { (Bankia / Santander...) }\end{array}$ & $\begin{array}{l}\text { García de los Salmones et al. } \\
\text { social works favoring the disadvantaged } \\
\text { Is concerned to improve general well-being of } \\
\text { society }\end{array}$ \\
\hline
\end{tabular}




\begin{tabular}{|c|c|c|}
\hline & $\begin{array}{l}\text { Has a role in society that goes beyond the } \\
\text { generation of profits }\end{array}$ & \\
\hline $\begin{array}{l}\text { CONSUMER } \\
\text { ATTRIBUTIONS } \\
\text { (Bankia / Santander is } \\
\text { carrying out this } \\
\text { philanthropic activity } \\
\text { because...) }\end{array}$ & $\begin{array}{l}\text { They feel morally obligated to help } \\
\text { They have a long-term interest in the } \\
\text { community } \\
\text { They are trying to give something back to the } \\
\text { community } \\
\text { They feel their customers expect it } \\
\text { They feel their stockholders expect it } \\
\text { They feel society in general expects it } \\
\text { They will get more customers by making this } \\
\text { offer } \\
\text { They will keep more of their customers by } \\
\text { making this offer } \\
\text { They are taking advantage of the social cause } \\
\text { to help their own business } \\
\text { They want to improve their image } \\
\text { They hope to increase profits by making this } \\
\text { social activity } \\
\text { They want to get a tax write-off }\end{array}$ & $\begin{array}{l}\text { Rifon et al. 2004; Ellen et al. } \\
\text { 2006; Groza et al. } 2011\end{array}$ \\
\hline $\begin{array}{l}\text { EMOTIONS } \\
\text { When I'm seeing this ad I } \\
\text { feel... }\end{array}$ & $\begin{array}{l}\text { Interest } \\
\text { Curiosity } \\
\text { Sympathy } \\
\text { Affection } \\
\text { Liking } \\
\text { Skepticism } \\
\text { Confusion } \\
\text { Anger } \\
\text { Suspicion } \\
\text { Distrust }\end{array}$ & $\begin{array}{l}\text { Batra and Ray, 1986; Burke and } \\
\text { Edell, 1986; Aaker et al. 1988; } \\
\text { Homer and Yoon, } 1992\end{array}$ \\
\hline $\begin{array}{l}\text { ATTITUDE TOWARD } \\
\text { THE AD } \\
\text { My general impression } \\
\text { about this ad is... }\end{array}$ & $\begin{array}{l}\text { Good } \\
\text { Positive } \\
\text { Favorable }\end{array}$ & $\begin{array}{l}\text { McKensie and Lutz, 1989; Lafferty } \\
\text { et al. 2002; Garcia de los Salmones, } \\
\text { et al. } 2013\end{array}$ \\
\hline $\begin{array}{l}\text { ATTITUDE TOWARD } \\
\text { THE BRAND } \\
\text { After seeing this ad,... }\end{array}$ & $\begin{array}{l}\text { My opinion about Bankia/Santander has improved } \\
\text { The image I have about Bankia/Santander has } \\
\text { improved } \\
\text { My awareness about Bankia/Santander has } \\
\text { improved } \\
\text { I feel greater trust about Bankia/Santander } \\
\text { I feel greater identification with Bankia/Santander }\end{array}$ & Du et al. 2010 \\
\hline $\begin{array}{l}\text { BEHAVIOUR } \\
\text { INTENTIONS }\end{array}$ & $\begin{array}{l}\text { It is likely I am client/remain client of } \\
\text { Bankia/Santander in the short term } \\
\text { I am planning to be client/remain client of } \\
\text { Bankia/Santander in the short term } \\
\text { I could say positive things about (Y) } \\
\text { I would recommend Santander/Bankia if somebody } \\
\text { asked my advice }\end{array}$ & $\begin{array}{l}\text { Zeinthaml et al. 2006; García de los } \\
\text { Salmones et al. } 2005\end{array}$ \\
\hline
\end{tabular}


Figure 1. Causal model

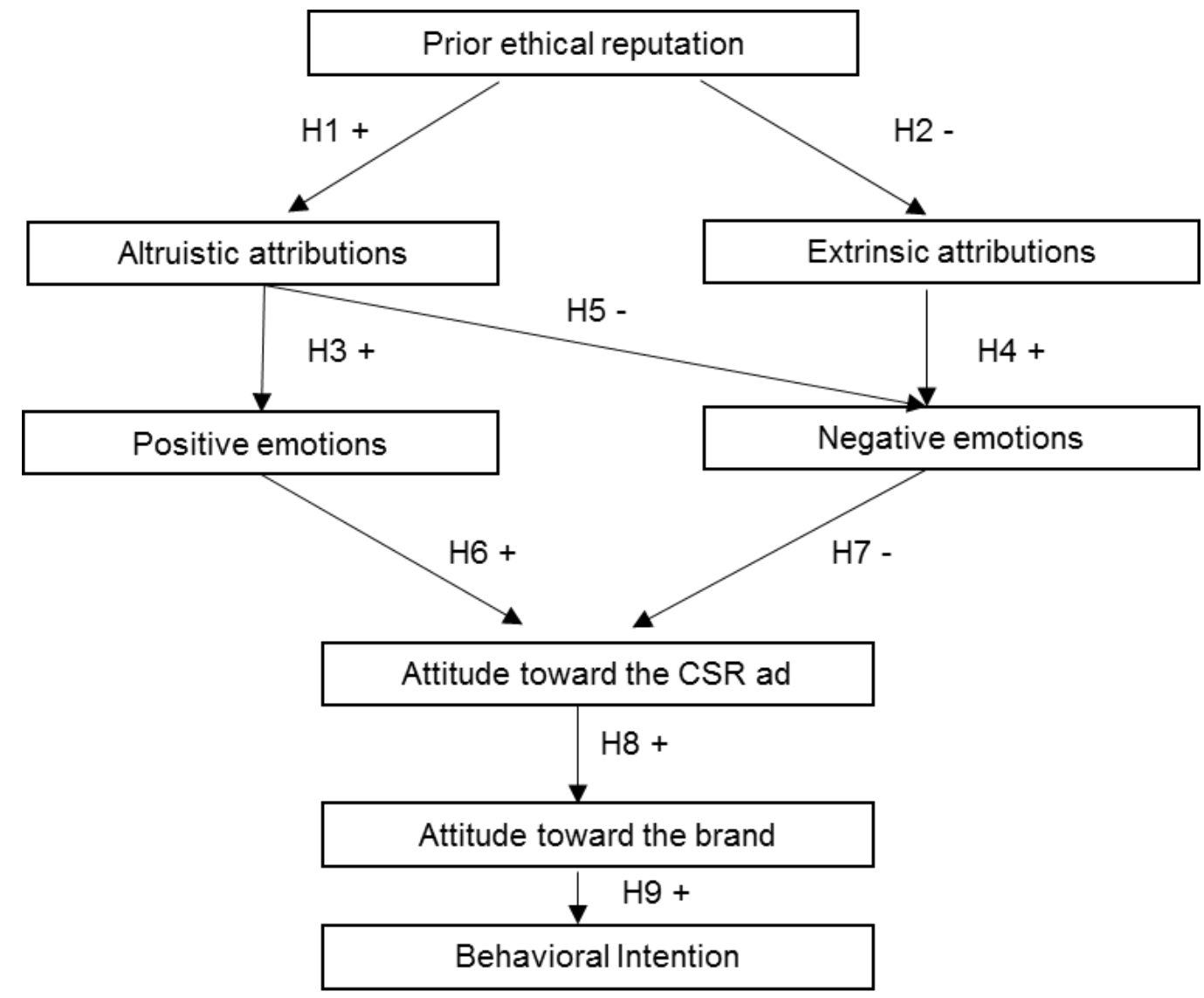


Table 1. Description of the samples

\begin{tabular}{|l|l|c|c|}
\hline \multicolumn{2}{|l|}{} & Bankia (n=105) & Santander (n=120) \\
\hline \multirow{3}{*}{ Gender } & Male & $45,7 \%$ & $48,3 \%$ \\
\cline { 2 - 4 } & Female & $54,3 \%$ & $51,7 \%$ \\
\hline Age & $18-35$ & $26,7 \%$ & $28,3 \%$ \\
\cline { 2 - 4 } & $36-54$ & $45,7 \%$ & $42,5 \%$ \\
\cline { 2 - 4 } & More than 55 & $27,6 \%$ & $29,2 \%$ \\
\hline \multirow{2}{*}{$\begin{array}{l}\text { Prior ethical reputation } \\
\text { (media of all the items of } \\
\text { the scale) }\end{array}$} & Clients & 4,9 & 6,5 \\
\cline { 2 - 4 } & No clients & 3,6 & 5,6 \\
\cline { 2 - 4 } & Total* & 3,8 & 6,0 \\
\hline
\end{tabular}

* $\mathrm{F}=85,763 ; 0,000$ 
Table 2: Factorial structure of the attribution of motivations towards a philanthropic activity

\begin{tabular}{|c|c|c|}
\hline \multicolumn{2}{|c|}{ Factor 1 - Altruistic attributions } & \multirow{2}{*}{$\frac{\text { Factor loadings }}{0,85}$} \\
\hline VA1 & They feel morally obligated to help & \\
\hline VA2 & They have a long-term interest in the community & 0,82 \\
\hline VA3 & They are trying to give something back to the community & 0,78 \\
\hline \multicolumn{2}{|c|}{ Eigenvalue } & 5,40 \\
\hline \multicolumn{2}{|c|}{ \% variance explained } & 28,27 \\
\hline \multicolumn{2}{|c|}{ Factor 2 - Business attributions } & Factor loadings \\
\hline BA1 & They feel their customers expect it & 0,77 \\
\hline BA2 & They feel their stockholders expect it & 0,70 \\
\hline BA3 & They feel society expects it & 0,81 \\
\hline BA4 & They will get more customers by making this offer & 0,73 \\
\hline BA5 & They will keep more of their customers by making this offer & 0,68 \\
\hline BA6 & They want to improve their image & 0,59 \\
\hline \multicolumn{2}{|c|}{ Eigenvalue } & 2,15 \\
\hline \multicolumn{2}{|c|}{ \% variance explained } & 24,41 \\
\hline \multicolumn{2}{|c|}{ Factor 3 - Profit attributions } & Factor loadings \\
\hline EA1 & They are taking advantage of the social cause to help their own business & 0,86 \\
\hline EA2 & They hope to increase profits by making this social activity & 0,90 \\
\hline EA3 & They want to get a tax write-off & 0,87 \\
\hline \multicolumn{2}{|c|}{ Eigenvalue } & $\begin{array}{l}1,08 \\
\end{array}$ \\
\hline \multicolumn{2}{|c|}{ \% variance explained } & 19,29 \\
\hline
\end{tabular}


Table 3: Confirmatory factor analysis

\begin{tabular}{|c|c|c|c|c|c|}
\hline Latent factors & Mean & Measured variable & $\begin{array}{l}\text { Standar } \\
\text { lambda }\end{array}$ & $\mathbf{R}^{2}$ & Cronbach's $\alpha$ \\
\hline \multirow{6}{*}{$\begin{array}{l}\text { F1.Prior ethical } \\
\text { reputation }\end{array}$} & \multirow{6}{*}{5,0} & Honesty & 0,92 & 0,85 & \multirow{6}{*}{0,96} \\
\hline & & Ethical principles & 0,95 & 0,89 & \\
\hline & & Truthful claims & 0,92 & 0,85 & \\
\hline & & General well-being & 0,92 & 0,84 & \\
\hline & & Donations & 0,79 & 0,68 & \\
\hline & & Role in society & 0,82 & 0,63 & \\
\hline \multirow{3}{*}{ F2.Altruistic attributions } & \multirow{3}{*}{5,5} & Morally obligated & 0,60 & 0,34 & \multirow{3}{*}{0,79} \\
\hline & & Long-term interest & 0,87 & 0,76 & \\
\hline & & Give something back & 0,79 & 0,62 & \\
\hline \multirow{6}{*}{ F3.Business attributions } & \multirow{6}{*}{7,1} & Customer & 0,78 & 0,61 & \multirow{6}{*}{0,87} \\
\hline & & Stockholders & 0,69 & 0,47 & \\
\hline & & Society & 0,85 & 0,72 & \\
\hline & & Get more customers & 0,70 & 0,49 & \\
\hline & & Keep more customers & 0,68 & 0,46 & \\
\hline & & Image & 0,71 & 0,50 & \\
\hline \multirow{3}{*}{ F4. Profit attributions } & \multirow[b]{3}{*}{7,9} & Help their own business & 0,84 & 0,70 & \multirow{3}{*}{0,91} \\
\hline & & Profits & 0,95 & 0,90 & \\
\hline & & Tax write-off & 0,85 & 0,72 & \\
\hline \multirow{5}{*}{ F5.Positive emotions } & \multirow{5}{*}{5,9} & Interest & 0,74 & 0,55 & \multirow{5}{*}{0,90} \\
\hline & & Curiosity & 0,64 & 0,42 & \\
\hline & & Sympathy & 0,94 & 0,89 & \\
\hline & & Affection & 0,88 & 0,78 & \\
\hline & & Liking & 0,73 & 0,53 & \\
\hline \multirow{5}{*}{ F6.Negative emotions } & \multirow{5}{*}{3,8} & Skepticism & 0,95 & 0,89 & \multirow{5}{*}{0,88} \\
\hline & & Confusion & 0,52 & 0,36 & \\
\hline & & Anger & 0,60 & 0,27 & \\
\hline & & Suspicion & 0,87 & 0,77 & \\
\hline & & Distrust & 0,87 & 0,75 & \\
\hline \multirow{3}{*}{ F7.Attitude toward the ad } & \multirow{3}{*}{6,41} & Good & 0,93 & 0,87 & \multirow{3}{*}{0,97} \\
\hline & & Positive & 0,97 & 0,94 & \\
\hline & & Favorable & 0,97 & 0,95 & \\
\hline \multirow{5}{*}{$\begin{array}{l}\text { F8. Attitude toward the } \\
\text { brand }\end{array}$} & \multirow{5}{*}{5,1} & Opinion improved & 0,95 & 0,89 & \multirow{5}{*}{0,98} \\
\hline & & Image improved & 0,98 & 0,96 & \\
\hline & & Awareness & 0,96 & 0,93 & \\
\hline & & Greater trust & 0,93 & 0,86 & \\
\hline & & Greater identification & 0,92 & 0,84 & \\
\hline \multirow{4}{*}{ F9.Behavioral intentions } & \multirow{4}{*}{4,8} & Likely client/remain client & 0,80 & 0,64 & \\
\hline & & $\begin{array}{c}\text { Plan to be client/remain } \\
\text { client }\end{array}$ & 0,78 & 0,61 & 0,95 \\
\hline & & Positive things & 0,98 & 0,96 & \\
\hline & & Recommendation & 0,96 & 0,93 & \\
\hline
\end{tabular}


Table 4: Discriminant validity*

\begin{tabular}{|c|c|c|c|c|c|c|c|c|c|}
\hline & F1 & F2 & F3 & F4 & F5 & F6 & F7 & F8 & F9 \\
\hline F1 & - & $\begin{array}{c}0,512 \\
(0,38,0,64)\end{array}$ & $\begin{array}{c}0,374 \\
(0,23,0,51)\end{array}$ & $\begin{array}{c}0,043 \\
(-0,11,0,201)\end{array}$ & $\begin{array}{c}0,460 \\
(0,3,3-0,58)\end{array}$ & $\begin{array}{c}-0,466 \\
(0,58,-0,35)\end{array}$ & $\begin{array}{c}0,495 \\
(0,37-0,61)\end{array}$ & $\begin{array}{c}0,668 \\
(057-0,76)\end{array}$ & $\begin{array}{c}0,79 \\
(0,73-0,86)\end{array}$ \\
\hline F2 & - & - & $\begin{array}{c}0,484 \\
(0,32,-0,66)\end{array}$ & $\begin{array}{c}0,135 \\
(-0,03,0,30)\end{array}$ & $\begin{array}{c}0,431 \\
(0,29,0,56)\end{array}$ & $\begin{array}{c}-0,352 \\
(-0,49,-0,21)\end{array}$ & $\begin{array}{c}0,467 \\
(0,32,0,61)\end{array}$ & $\begin{array}{c}0,647 \\
(0,54,0,74)\end{array}$ & $\begin{array}{c}0,503 \\
(0,37,0,62)\end{array}$ \\
\hline F3 & - & - & - & $\begin{array}{c}0,604 \\
(0,47-0,73)\end{array}$ & $\begin{array}{c}0,218 \\
(0,05,0,38)\end{array}$ & $\begin{array}{c}-0,052 \\
(-0,19,0,09)\end{array}$ & $\begin{array}{c}0,230 \\
(0,06,0,39)\end{array}$ & $\begin{array}{c}0,298 \\
(0,15,0,44)\end{array}$ & $\begin{array}{c}0,415 \\
(0,29,0,53)\end{array}$ \\
\hline F4 & - & - & - & - & $\begin{array}{c}0,059 \\
(-0,10,0,22)\end{array}$ & $\begin{array}{c}0,193 \\
(0,06,0,32)\end{array}$ & $\begin{array}{c}-0,018 \\
(-0,19,0,15)\end{array}$ & $\begin{array}{c}-0,071 \\
(-0,22,0,08)\end{array}$ & $\begin{array}{c}0,089 \\
(-0,06,0,24)\end{array}$ \\
\hline F5 & - & - & - & - & - & $\begin{array}{c}-0,469 \\
(-0,60,-0,33)\end{array}$ & $\begin{array}{c}0,82 \\
(0,77,0,88)\end{array}$ & $\begin{array}{c}0,637 \\
(0,53,0,73)\end{array}$ & $\begin{array}{c}0,450 \\
(0,33,0,57)\end{array}$ \\
\hline F6 & - & - & - & - & - & - & $\begin{array}{c}-0,51 \\
(-0,64,-0,39)\end{array}$ & $\begin{array}{c}-0,559 \\
(-0,66,-0,45)\end{array}$ & $\begin{array}{c}-0,422 \\
(-0,53,-0,30)\end{array}$ \\
\hline F7 & - & - & - & - & - & - & - & $\begin{array}{c}0,676 \\
(0,59,0,76)\end{array}$ & $\begin{array}{c}0,495 \\
(0,38,0,60)\end{array}$ \\
\hline F8 & - & - & - & - & - & - & - & - & $\begin{array}{c}0,678 \\
(0,58,0,77)\end{array}$ \\
\hline
\end{tabular}

* The figures indicate the correlation between pairs of latent factors and the confidence intervals. 
Figure 2. Final model

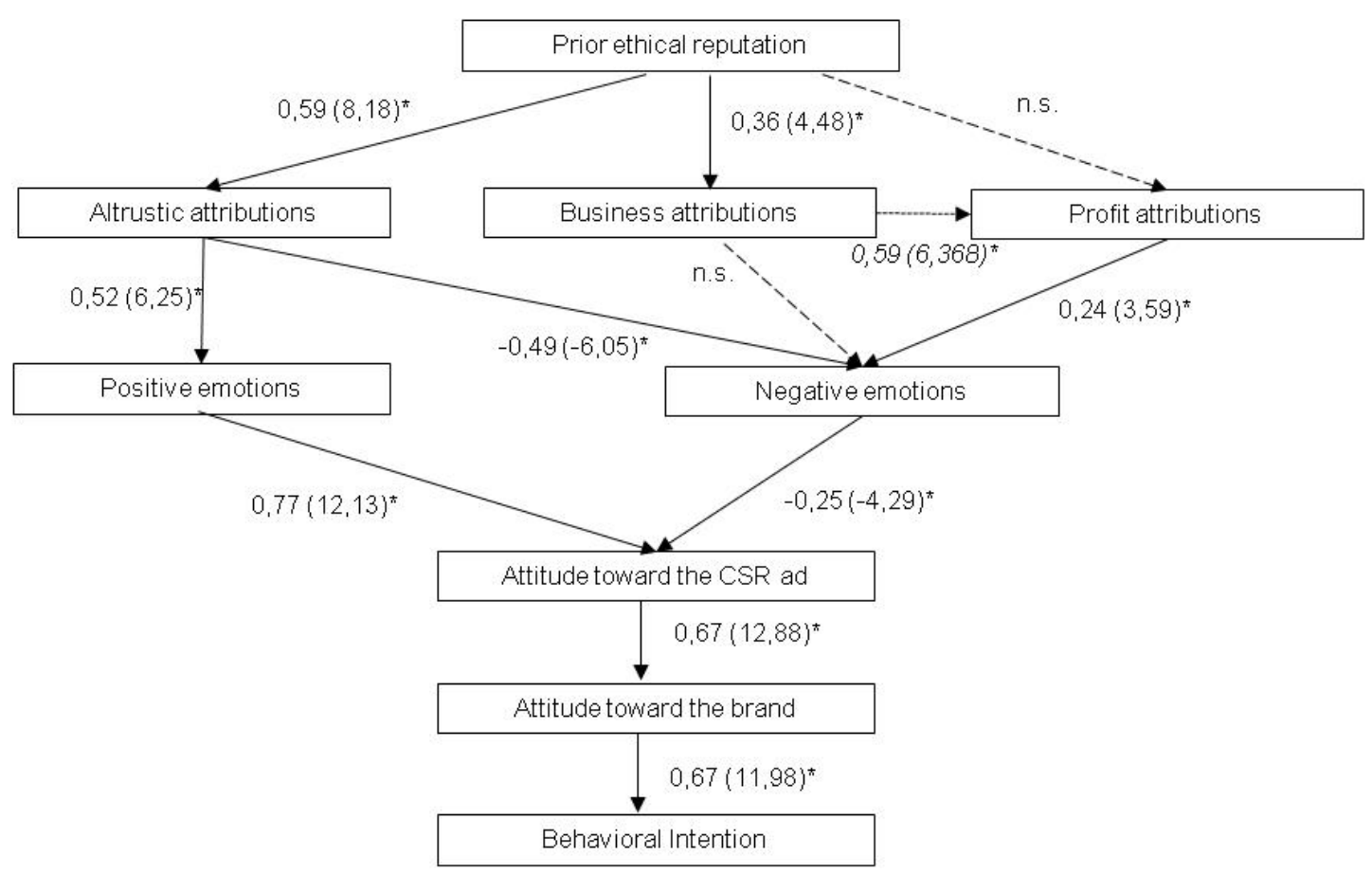

${ }^{*} \mathrm{p}<0,05 ;$ Goodness of fit: BBNFI=0,84; BBNNFI=0,90; CFI=0,91; $|F|=0,91 ;$ RMSEA=0,06

$\longrightarrow$ New significant relationship 